Will industry bail out the Australian education system?

Sydney

A SPIRITED public debate about the financing of higher education in Australia has been triggered by the estimates in the federal government's green paper (consultative document) that increases in student enrolment by the end of the century will result in a $\mathrm{A} \$ 1,000-2,000$ million deficit in tertiary education budgets.

Acknowledging the potential problem, the Minister for Employment, Education and Training, Mr John Dawkins, has convened a committee headed by a former New South Wales Premier, Mr Neville Wran, to investigate aiternative ways of raising extra funds. But the various groups on whom the financial burden is likely to fall are making their views heard in advance of the committee's recommendations to the government, due on 3 May.

One option is to make students responsible. Wran has ruled out the reintroduction of tertiary fees on the pre-1974 pattern, but academic and student groups have already mounted a campaign against any form of fees system.

Another option is a tax deducted from the wages of graduates above some recouped, but there are difficulties. Geoffrey Lehmann, a senior national tax consultant, says that the "imposition of a graduate tax would result in massive tax avoidance and an exodus of young graduates from Australia".

According to union and student groups, a better course of action would be to seek extra financial support from industry, as corporations are the main beneficiaries of graduates leaving the tertiary education system. There are two proposals for increased participation from business. One calls for a 2 per cent tax on company revenues, providing a return of $\mathrm{A} \$ 330$ million. Or employer contributions might take the form of a fund to provide money for student training schemes.

But employer groups are strongly opposed to such mandatory programmes. George Hutton, assistant director of the Business Council of Australia, says that "further taxes and levies" would reduce the ability of the business communities to employ graduates and that it is for individual companies to decide how their money is spent.

income threshold until education costs are

Tania Ewing

\title{
Bennett and Stanford tangle on restructured curriculum
}

Berkeley

US SECretary of Education William Bennett let loose a verbal barrage against Stanford University last week in his campaign for a return to traditional standards for US undergraduate education. $\mathrm{He}$ accused Stanford of "trashing Western culture" by restructuring its core course on Western culture to include issues of gender, race and class, and elements of non-Western culture. Bennett says Stanford's decision was political, not educational and that it represents a "capitulation to a campaign of pressure politics and intimidation" by students.

Bennett fears that where Stanford leads others will follow. His most recent criticisms came in a speech on 18 April at Stanford itself, followed by a televised exchange with Stanford president Donald Kennedy. Kennedy accused Bennett of using "the privilege of his pulpit to bully rather than to engage the issues". Stanford faculty on both sides of the issue have expressed surprise at Bennett's meddling in Stanford's affairs, and say he is misinformed about the process that shaped the curriculum change.

Stanford had required a one-year course in Western civilization of all entering students. Freshmen choose from eight options each with a unique focus, such as 'Great Works' or 'Values, Technology, Science and Society', but all bound together by a required reading list of 15

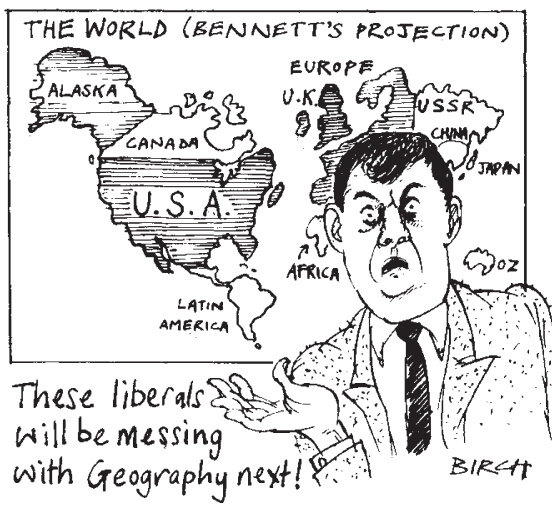

classic Western works, to which faculty members may make their own additions.

The core reading list has been criticized by both students and faculty for not sufficiently representing the contributions of women and non-Western cultures. This led, in 1986, to the appointment of a task force to examine and redesign the course.

After two years of debate, at least one work from a non-Western culture and three works dealing with issues of gender, class or race will be incorporated in each

\section{Lords fight for academic freedom}

\section{London}

THE British government's proposals to reform the financing and management of higher education continue to run into fierce opposition, despite an earlier promise of several concessions (see Nature 331, 645; 1988). Last week it was the turn of peers, when the Education Reform Bill had its second-reading debate in the House of Lords. Attention focused on the question of the protection of intellectual freedom following the abolition of the universities' right to offer tenure to academic staff.

Lord Jenkins, chancellor of the University of Oxford and one of the country's most distinguished parliamentarians, said the bill as it stood made him "extremely doubtful whether we will have a university of foremost world class in the country by the end of the century". The Lord Chancellor, Lord Mackay, insisted that the government had not "closed its ears or minds" to suggestions to include a specific reference to academic freedom in the bill. The matter would be reconsidered at the committee stage. He reminded peers that the government had already stated its intention to include amendments to set up grievance procedures that would ensure the protection of intellectual freedom.

Before the debate, a newly formed pressure group, the Committee of University Autonomy, presented the Lords with a petition carrying the signatures of 6,000 academics protesting against the "current threat to our universities and colleges and to their intellectual liberties". The committee says that a university's ability to offer tenure is an important selling point in an increasingly competitive international market place and that if the government refused specifically to protect academic freedom, more staff would seek secure positions abroad.

Simon Hadlington

option. The core list of Western works has not been abandoned, but will be revised each year. Next year's list includes the Bible and works by Machiavelli, Rousseau, Plato, St Augustine and Marx.

Bennett has criticized Stanford administrators for basing their decision not on "enlightened debate" but on "tactics of intimidation" by student factions. Those involved seem to disagree. Economics professor Kenneth Arrow, an opponent of the new curriculum, called the motives for change "responsible and thoughtful" and denied that faculty senate members had responded to student pressure. The faculty senate voted 39 to 4 on 31 March to approve a compromise that retains a core list but allows greater freedom for incorporating other works, including those dealing with the newly designated issues.

Marcia Barinaga 